REVIEW

\title{
Gene therapy in clinical medicine
}

\section{S M Selkirk}

Postgrad Med J 2004;80:560-570. doi: 10.1136/pgmj.2003.017764

Although the field of gene therapy has experienced significant setbacks and limited success, it is one of the most promising and active research fields in medicine. Interest in this therapeutic modality is based on the potential for treatment and cure of some of the most malignant and devastating diseases affecting humans. Over the next decade, the relevance of gene therapy to medical practices will increase and it will become important for physicians to understand the basic principles and strategies that underlie the therapeutic intervention. This report reviews the history, basic strategies, tools, and several current clinical paradigms for application.

Correspondence to:

Dr S Selkirk, Department of

Neurology, University

Hospital of Cleveland

Hanna House 5, 11100

Euclid Avenue, Cleveland,

$\mathrm{OH} 44106$, USA;

stephen_selkirk@

hotmail.com

Submitted

9 December 2003

Accepted 13 March 2004
$\mathrm{T}$ he potential for treating a patient using gene transfer has been realised in an exponential fashion, paralleling advances in molecular biology over the last four decades. ${ }^{1-4}$ One of the earliest indications that gene transfer might be used therapeutically was proposed from a plant cell experiment in 1968. Rogers suggested that: "the next step was to build a modified virus... and use the virus to transmit...information". ${ }^{5}$

Throughout the 1970s and 1980s, basic science pushed the field of gene therapy to its first clinical trial in $1988 .^{6-18}$ However, clinical trials to date have been widely unsuccessful and have led many physicians and scientists to doubt the potential of the modality. Recent events have furthered this notion. The death of a patient involved in a University of Pennsylvania gene therapy clinical trial was a troubling development, which led to increased scrutiny of human protocols and a public backlash regarding the general safety of gene therapy. ${ }^{19} 20$

The "cure" of several young patients with severe combined immunodeficiency was lauded as the first significant clinical step forward for gene therapy. ${ }^{21} 22$ However, recent reports have detailed the development of a leukaemic syndrome in several of these patients. ${ }^{23}$ Furthermore, the leukaemia was discerned to be a direct result of the therapeutic intervention. More specifically, the viral vector produced insertional mutagenesis when incorporating into the patient's genome. $^{24}$ The development has again called into question the general safety of the current technology available for gene transfer.

\section{STRATEGIES FOR GENE DELIVERY In vivo gene therapy}

Two approaches for delivering genetic material exist: in vivo and ex vivo. The in vivo strategy involves the direct delivery of DNA (usually via a viral vector) to resident cells of the target tissue (fig 1). There are two requirements for such a strategy: firstly, that target cells be easily accessible for infusion or injection of virus, and secondly, that the transfer vector readily and specifically infects, integrates, and then expresses the therapeutic gene (transgene) in target cells and not surrounding cells at effective levels for extended time periods.

A discussion of all available viral vectors is beyond the scope of this review. The characteristics of the most commonly used vectors are listed in table 1. Retroviral vectors derived from the mouse Moloney leukaemia virus (MMLV) and herpes simplex virus (HSV) derived vectors are of limited value in most in vivo clinical situations. ${ }^{25-27}$ However, in vivo application in several diseases has been established, such as HSV in peripheral neuropathies ${ }^{28-30}$ and retroviral vectors for malignancies. ${ }^{31}{ }^{32}$ The use of nonviral, lipophilic molecules to transfer genetic material to cells in vivo has been limited by low transfer efficiency. ${ }^{33}$

Adenoviral vectors are the mainstay of in vivo strategies owing to their high transfection efficiency. However, the virus is plagued by antigenecity $^{34}$ and is limited to short term expression of transgenes because it does not permanently integrate into the host genome. ${ }^{35}$ "Gutless" adenoviral vectors, which lack antigenic factors, and adenoassociated virus vectors (AAV), which have limited ability to integrate into the host genome have both been described and are under investigation as possible substitutes for the traditional adenoviral vector. ${ }^{36-39}$

Currently the lentivirus derived vectors appear to be the most promising for future in vivo clinical applications. The lentivirus is a species of the family Retroviridae, which can infect both non-dividing and dividing cells. Lentiviruses have evolved more complex genomes that contain regulatory genes and accessory genes in addition to the structural genes gag, pol, and env. These additional genes allow the virus to traverse not only the cellular, but also the nuclear membrane without prerequisite membrane disruption, ${ }^{40}$ as is required by MMLV. This allows

Abbreviations: $A A V$, adenoassociated virus; $A D$, Alzheimer's disease; BMD, Becker's muscular dystrophy; $C A B G$, coronary artery bypass; $C A D$, coronary artery disease; CF, cystic fibrosis; CFTR, cystic fibrosis transmembrane regulator; CNS, central nervous system; DMD, Duchenne muscular dystrophy; HSV, herpes simplex virus; $\mathrm{MI}$, myocardial infarction; MMLV, mouse Moloney leukaemia virus; NGF, nerve growth factor; PVD, peripheral vascular disease; shRNA, short hairpin RNA; siRNA, short interfering RNA; VEGF, vascular endothelial growth factor 


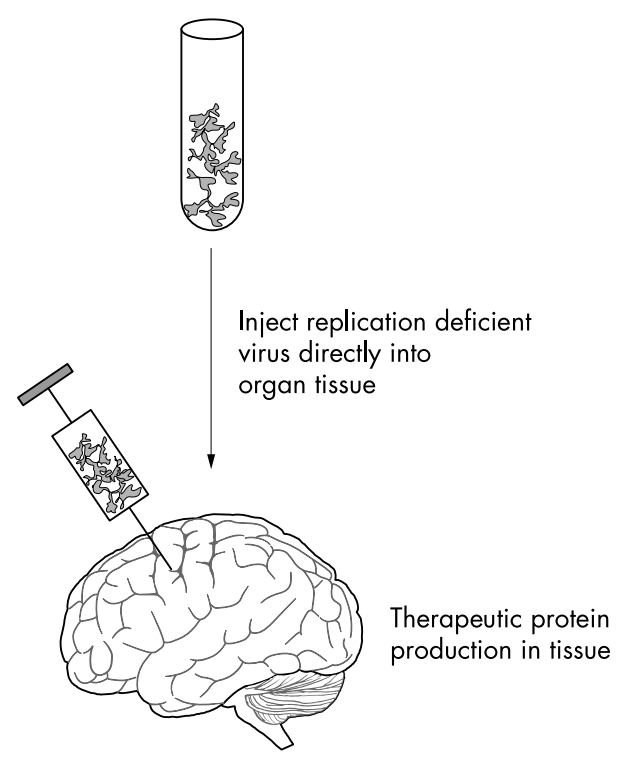

Figure 1 In vivo gene transfer. The in vivo strategy is based on the production of replication deficient virus in vitro followed by direct injection (or infusion) of the virus into an organ system. The virus genetic material will incorporate into cells and therapeutic genes will be expressed.

the virus to integrate into non-dividing cells. This factor, coupled with long term expression of transgenes and lack of antigencity, make lentiviral vectors one of the more promising new transfer methods available.

Safety issues have arisen with the proposed use of lentiviral vectors in human studies ${ }^{41}$ because they are derived from immunodeficiency viruses, including HIV, and have the theoretical potential to generate a self replicating virus through recombinatorial events in the packaging cell line. To address this issue, the current packaging cell line requires transient transfection with three distinct plasmids, all containing gene sequences required for an active infectious virus. This system makes the possibility of three recombination events occurring in one cell to produce an actively infectious product extremely unlikely. ${ }^{42-44}$

\section{Ex vivo gene therapy}

The ex vivo approach involves the transfer of a therapeutic gene to cells in vitro (in culture) followed by transplantation of these modified cells to the target tissue (fig 2). The modified, transplanted cells act as an engineered secretory

\begin{tabular}{|c|c|c|}
\hline Method & Advantages & Disadvantages \\
\hline Herpes simplex virus & Broad infectivity & $\begin{array}{l}\text { Cytotoxic, low titres, and short term episomal } \\
\text { expression }\end{array}$ \\
\hline Adenovirus & $\begin{array}{l}\text { High titres, infects non-dividing } \\
\text { cells }\end{array}$ & $\begin{array}{l}\text { Life threatening immunogenecity. Short term } \\
\text { episomal expression only }\end{array}$ \\
\hline Adenoassociated virus & $\begin{array}{l}\text { Broad infectivity, infects non- } \\
\text { dividing cells, non-cytopathic }\end{array}$ & Short term expression with limited integration \\
\hline Lentivirus & $\begin{array}{l}\text { Permanently infects non-dividing } \\
\text { cells. High viral titres }\end{array}$ & Safety concerns owing to HIV derivation \\
\hline Retrovirus & $\begin{array}{l}\text { Permanent integration, well } \\
\text { characterised }\end{array}$ & $\begin{array}{l}\text { Poor infection efficiency. Does not infect non- } \\
\text { dividing cells }\end{array}$ \\
\hline Liposomes & Avoids use of cytopathic virus & Low efficiency of transfection of cells \\
\hline
\end{tabular}

Figure 2 Ex vivo gene transfer. The ex vivo strategy is based on the utilisation of a surrogate cell that is infected with virus in vitro. The surrogate cell is subsequently transferred to the target tissue and expresses the therapeutic gene.

tissue, synthesising and releasing desired proteins to the local environment.

In order to exploit the method successfully, an appropriate surrogate cell population must be identified. This cell population should be endowed with specific characteristics that fulfil several criteria. The cells should: (1) be readily available and relatively easily obtained; (2) be able to survive for long periods of time in vivo; (3) be able to express a transgene at high levels for extended durations; and (4) and not elicit a host mediated immune reaction. 
The advantages of using an ex vivo approach include the ability to fully characterise the modified cell population before transplantation, the ability to subclone cells and produce monoclonal populations that produce high levels of therapeutic protein, and the ability to screen populations and exclude the presence of helper viruses, transformational events, or other deleterious properties obtained after or during the modification process. Furthermore, viral vectors of low transfection efficiency can be used, because uninfected cells can be selected out of the transplant population.

Multiple surrogate cells have been proposed as delivery vehicles for therapeutic genetic material (table 2). Currently, autologous primary cell cultures remain the most attractive candidate for surrogate cell delivery systems, and many experiments have demonstrated the usefulness of this cell type. Primary, adult astrocytes have been harvested and modified in vitro and have demonstrated the ability to effectively transfer genetically material to the central nervous system (CNS) for extended time periods.$^{45}$ Primary fibroblasts are an alluring surrogate cell because they can proliferate in culture, yet remain contact inhibited and non-transformed, even after multiple passages in vitro. Furthermore, these cells can be easily harvested from the host, allowing for autologous cell transplantation. Many studies have demonstrated the utility of using primary fibroblasts for gene transfer, ${ }^{46}{ }^{47}$ and a current clinic trial is underway using these cells in an ex vivo strategy to treat Alzheimer's disease..$^{48}$ The advantage of using primary, autologous cell cultures include the lack of antigenicity and decreased risk of malignant transformation relative to immortalised cell lines. Disadvantages include difficulty in harvesting some types of primary cells, maintaining them in culture, and effectively expressing transgenes through current transfection techniques. Another complication arises when primary cells are transferred to non-host tissue; for example, primary fibroblasts transplanted to the CNS will often produce collagen and other skin appropriate products that interfere with normal CNS functioning. ${ }^{49}$ This problem may be overcome with the use of stem cells.

Adult stem cells have become a viable option for gene transfer over the past decade and are similar to primary cell cultures. However, adult stem cells offer the potential to completely incorporate into any host tissue and transform into a mature cell of that organ. This ability ensures long term survival of grafted cells, which function in concert with the resident cells of that organ system. Peripheral derived haematopoietic stem cells are of particular interest as a potential surrogate cell. The plasticity of this cell type has been widely reported; bone marrow derived glial cells have been identified in focal ischaemic rat brain, ${ }^{50}$ and bone marrow derived myocardial cells have been identified in rat models of cardiac ischaemia. ${ }^{51} 52$ This underlines the major advantage of stem cells over primary cells; the possibility that these cells could be used not only to carry therapeutic proteins, but also to repopulate organs with damaged or depleted cell numbers. Haemopoietic stem cells are easily obtained through basic peripheral intravenous access systems, allowing for marrow derived stem cells to be harvested systemically, modified in vitro, and under the correct circumstances re-infused into the peripheral blood with subsequent homing to damaged target tissue such as brain or myocardium.

Bone marrow derived stem cell use has been limited by low viral transfection efficiency ${ }^{53}{ }^{54}$ and technical difficulties in isolating, culturing, and maintaining these cells. Other adult stem cells include hepatocytes, which have been obtained through partial liver transections, and have been isolated, manipulated in culture, and then re-infused into autologous liver. ${ }^{55}$ CNS stem cells have also been isolated but are not available for autologous transplant owing to the inaccessibility of these cells in the periventricular zone of the CNS. Most studies have used cadaver derived cells. ${ }^{56} 57$

Finally, fetal derived stem cells have been the topic of much scientific and media speculation. Fetal cell transplantation has been successful in multiple animal models of disease, ${ }^{58-62}$ and transfer of unmodified fetal cells has already been undertaken in Parkinson's disease. ${ }^{63-65}$ Patients with Parkinson's disease receiving fetal dopaminergic neurones have demonstrated clinically significant long term benefits. However, several patients obtained no benefit from the transplant and several developed worsening of symptoms. ${ }^{66-68}$ Similarly, transplantation of human fetal striatal tissue to patients with Huntington's disease has been undertaken. Results indicate that grafts derived from human fetal striatal tissue can survive regardless of the ongoing endogenous neurodegenerative process; however, the clinical benefit is unproven. ${ }^{69-71}$ Finally, fetal islet cells have been transplanted to patients with diabetes mellitus with variable success. In some cases the transplant has obviated the need for exogenous administration of insulin. ${ }^{72}{ }^{73}$ The fact that fetal cells can be maintained in culture, have some degree of plasticity, and can be transfected using classical methods make this cell type attractive. However, fetal derived primary cell cultures are often heterogeneous and difficult to define and purify. The success of graft survival appears to be related to the manner in which cells are prepared, purified, and transplanted, but the factors predicting a successful clinical response to graft transplantation are unclear. Further, fetal tissue is not readily accessible and continues to be part of a wider moral and ethical debate.

\begin{tabular}{|lll|}
\hline Table 2 Surrogate cell types & \\
\hline Cell type & Advantages & Disadvantages \\
\hline Transformed cell lines & $\begin{array}{l}\text { Easily obtained, cultured and } \\
\text { manipulated. Survive after transplant }\end{array}$ & $\begin{array}{l}\text { High degree of malignant transformation } \\
\text { of cells after transplant. Unsafe }\end{array}$ \\
Primary cell cultures & $\begin{array}{l}\text { Decreased risk of transformation. } \\
\text { Relatively easy to infect }\end{array}$ & $\begin{array}{l}\text { Can be difficult to obtain or culture. May } \\
\text { not survive long term after transplant }\end{array}$ \\
Adult stem cells & $\begin{array}{l}\text { Plasticity of cell type with ability to } \\
\text { potentially incorporate into target } \\
\text { organ tissue } \\
\text { Fetal stem cells }\end{array}$ & $\begin{array}{l}\text { Difficult to maintain in culture and to } \\
\text { infect while maintaining stem cell status }\end{array}$ \\
& $\begin{array}{l}\text { Plasticity of cell type has potential for } \\
\text { tissue }\end{array}$ & $\begin{array}{l}\text { Often heterogeneous and difficult to } \\
\text { purity. Moral and ethical problems } \\
\text { remain a major impedence to } \\
\text { availability. Heterologous transplant only }\end{array}$ \\
\hline
\end{tabular}




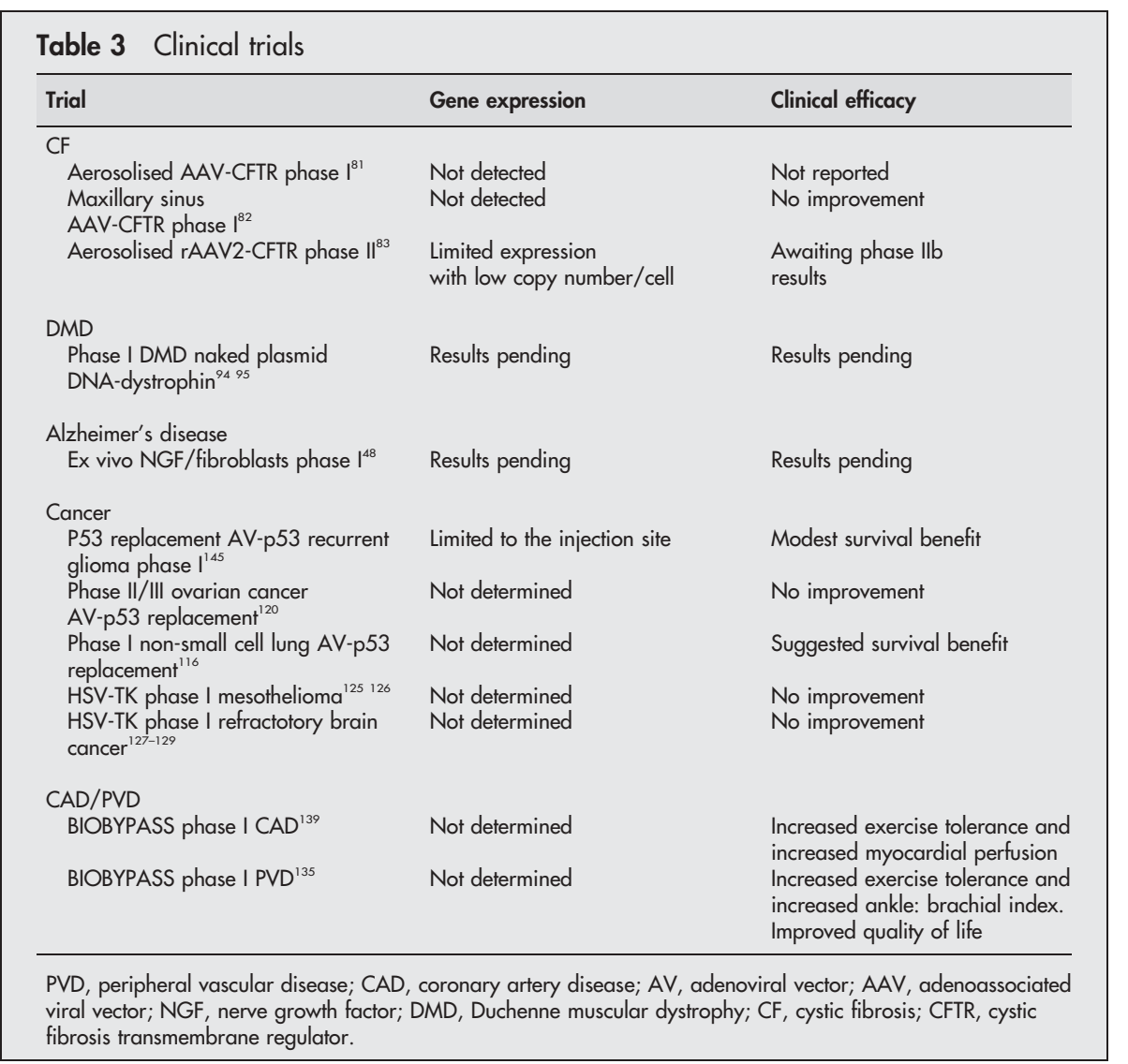

\section{GENE THERAPY APPLIED TO CLINICAL MEDICINE (TABLE 3) \\ Diseases caused by single gene mutations}

Diseases caused by a single defective gene represented an early target for corrective gene therapy. Diseases such as Duchenne muscular dystrophy (DMD) and cystic fibrosis (CF) have well established aetiologies and pathophysiologies, with clearly defined genetic mutations.

\section{Cystic fibrosis}

$\mathrm{CF}$ is caused by mutations in a gene on chromosome 7 , named cystic fibrosis transmembrane regulator (CFTR). This $230 \mathrm{~kb}$ gene encodes a 1480 amino acid protein that acts as a membrane chloride channel. ${ }^{74}$ As many as six different mutation types and 1000 specific mutations have been identified, and vary in frequency worldwide. ${ }^{76}$ The defect results in changes in multiple organ systems, most notably the lungs and pancreas, producing chronic lung infection, pancreatic insufficiency, and diabetes mellitus. The median survival in 2000 was 32 years. ${ }^{77}$

Restoration of the wild type CFTR could be curative. The first phase I clinical trials ever conducted using adenoviral vectors and AAV vectors involved the transfer of CFTR to CF patients. ${ }^{78} 79$ Trials using first and second generation adenoviral vectors have been limited by the inability to repeatedly administer the virus. The transient nature of the viral expression vector requires such a strategy, but the inflammation induced by these vectors prevented this. Early trials using AAV did not induce inflammation, but failed to demonstrate effective levels of transferred CFTR expression. ${ }^{79}{ }^{80}$ Target Genetics Corporation developed an adenoassociated virus tgAAVCF virus, expressing the CFTR gene, and has administered it to patients in an aerosolised form. Results showed that a single administration of the virus was well tolerated and safe, but virus derived CFTR expression was not detected in patients. Clinical efficacy was not reported. ${ }^{81}$ Phase II trials have also been reported using the same vector delivered to the maxillary sinuses of CF patients. Results confirmed the safety of tgAAVCF administration, but again failed to detect expression of the transferred CFTR gene in biopsy specimens and failed to demonstrate clinical improvement in treated patients. ${ }^{82} \mathrm{~A}$ phase I trial has recently been published using a second generation AAV (rAAV2) expressing CFTR. Result indicated that a single administration of the virus was safe with escalating virus concentration; however, the number of cells in the airway expressing the viral CFTR were limited and they contained a low copy number. Both results indicate inefficient transfer of genetic material using this virus. ${ }^{83}$ A phase IIb trial is underway to determine if the therapy improves lung function in CF patients. ${ }^{84}$

Similarly, early clinical trials using several different cationic lipid preparations were deemed safe and allowed for repeated administration of CFTR, but were inefficient in transferring the gene, and failed to demonstrate efficacy. ${ }^{85-88}$

Finally, a clinical trial is being undertaken by Copernicus Therapeutics Inc, using a novel method that allows for compaction of a single molecule of DNA condensed to the minimal possible volume. The small volume, positively charged particle is able to pass through cellular and nuclear membrane pores and allows delivery of genetic material to non-dividing cells. ${ }^{89}$ Transfer of genes using this technology has proven to be safe in animals, and subsequent phase I clinical trials in CF patients have been completed. ${ }^{90}$ In the study, patients received compacted DNA containing CFTR via the nasal passages. Results indicated that the administration is safe and tolerable. The treatment efficacy is not noted in the phase I trial. A phase II, multicentre, double blind, placebo controlled study is underway. ${ }^{91}$ 


\section{Duchenne muscular dystrophy}

DMD, the most prevalent muscular dystrophy, is caused by large deletions or insertions of the dystrophin gene. This very large gene (cDNA $14 \mathrm{~kb}$ ) encodes a 3685 amino acid protein ${ }^{92}$ that stabilises the muscle cell membrane. Its dysfunction results in destabilisation and subsequent degeneration of muscle tissue. ${ }^{93}$

As with CF, DMD is potentially curable with extensive transfer of the wild type dystrophin gene to muscle tissue. In a similar fashion, strategies are limited due to the large size of the dystrophin gene. Currently, a phase I trial has been initiated using plasmid dystrophin DNA. The naked plasmid is directly injected into the radial muscle in an attempt to determine tolerability and safety as well as gene expression..$^{95}$ Results have yet to be published. More promising clinical trials should be undertaken using viral vectors to produce "exon skipping" of mutated sequences of the dystrophin gene (discussed later).

\section{Other diseases}

Alzheimer's disease

Alzheimer's disease (AD) is the most common cause of dementia. AD generally affects individuals in their sixth and seventh decade, and is characterised by the insidious onset of cognitive changes manifesting initially as forgetfulness. Once the memory defect is established, defects in other areas of cerebral function become obvious, leading to behavioural disturbances including anxiety, agitation, and confusion. The progressive decline in cognitive function usually occurs over five to 10 years, ending with the patient bedridden and succumbing to pneumonia or other recurrent infection.

The disease course is tragic not only for the patient, but for the family and caregivers. It is estimated that four million Americans suffer from the disease, with an average yearly cost to the USA of $\$ 100$ billion. ${ }^{96}$ Current understanding of the pathophysiology is limited. Current treatment, consisting of acetylcholinesterase inhibitors, modestly retards symptomatic disease progression, but does not prevent neurone loss. ${ }^{97-99}$

However, basic research into neuroprotective factors (factors that prevent neuronal death) over the past two decades has now culminated in a phase I, gene therapy clinical trial for the treatment of $\mathrm{AD}$. The neuroprotective factor (neurotrophic factor) being utilised in the study is nerve growth factor (NGF). NGF was initially described in the 1950s after it was extracted from chick embryos and shown to promote neuronal survival. ${ }^{100}$ In the 1980s, several groups reported that NGF administration into brain parenchyma prevented the loss of cholinergic neurones in the forebrain following axotomy, ${ }^{101-103}$ and subsequently, NGF was shown to have an effect on age related CNS decline in normal rats. Initially, therapeutic methods focused on intracerebroventricular infusions of NGF to rescue dying neurones; however, several groups reported significant toxic side effects in mice. Successive observations in the early 1990s showed that this method of NGF delivery caused weight loss, decreased appetite, and hypertrophy of cells in the subpial space. ${ }^{104-106}$ Those animal studies foreshadowed the fate of an intracerebroventricular NGF infusion clinical trial, as three patients with $\mathrm{AD}$ receiving infusions developed adverse effects, leading to its premature cancellation. ${ }^{107}$

It became evident that an alternative delivery method was required if NGF was to be used therapeutically. Following multiple rat and primate gene therapy studies, including dose escalation studies, ${ }^{48}$ demonstrating the effectiveness and safety of NGF gene therapy in preventing neuronal loss and the absence of significant side effects, ${ }^{108}{ }^{109}$ an ambitious, phase I, ex vivo gene therapy clinical trial was initiated in 2000. Primary autologous fibroblasts were infected, in vitro, with an MMLV derived viral vector that expressed NGF constitively from a viral promoter sequence. These infected cells, expressing high levels of NGF, were then transplanted into the nucleus basillis of human subjects.

At the last published report the group had enrolled eight individuals in the phase I safety trial. All patients enrolled were early stage, with "probable" $\mathrm{AD}$ based on strict clinical research criteria. The study will terminate when all patients have been studied for one year post-transplantation. The goal of the study is to determine the effect of ex vivo gene therapy strategies for CNS disease and to determine if NGF can prevent clinical decline. ${ }^{48}$

\section{Cancer}

The second leading cause of death in the USA is cancer, with cancer deaths approaching 500000 annually, and one million cases of cancer diagnosed each year. ${ }^{110}$ Current methods of treatment, including chemotherapy, radiation therapy, and surgical debulking, are generally only effective for early stage disease. The more advanced the disease, the less effective the therapy becomes. Furthermore, the side effect profile of chemotherapy is horrifying and many treatment failures are due to intolerable side effects and the inability to continue with an entire treatment course. Many gene therapy clinical trials have been initiated since 1988 to treat cancer. Although multiple studies have been initiated and strategies proposed, only two broad strategies are discussed here.

Replacement gene therapy using $p 53$ is based on the broad concept that correction of a specific genetic defect in tumour cells can reverse uncontrolled cell growth. The wildtype p53 gene product is involved in the recognition of DNA damage and the subsequent correction of that defect or induction of apoptosis in that cell. ${ }^{11-113}$ The gene is altered in over $50 \%$ of human malignancies, ${ }^{114}$ and therefore, has become the fulcrum of multiple gene therapy replacement trials. The general strategy is an in vivo gene therapy approach using an adenoviral vector expressing the wildtype $p 53$ gene. The adenovirus delivery mechanism varies depending on where the tumour is located, and in all studies the therapy is combined with surgery, radiation, or chemotherapy, or a combination of the three. Clinical trials in various phases are underway for treatment of glioma, ${ }^{115}$ lung cancer, ${ }^{116}$ ovarian cancer, ${ }^{117}$ breast cancer, ${ }^{118}$ and recurrent head and neck cancer. ${ }^{119}$ Results published to date have been disappointing. Phase I trials for recurrent glioma reported only modest survival benefit and expression of adenoviral derived p53 only a short distance from the site of virus administration. ${ }^{115}$ Phase II/III trials for ovarian cancer failed to show treatment benefit with intraperitoneal administration of adenovirus expressing p53 with chemotherapy after debulking surgery. ${ }^{120}$ Finally, Swisher et al published antitumour effects associated with the treatment of non-small cell lung cancer; however, no comparable control group was described in their report. ${ }^{116}$

A more elegant strategy for the treatment of cancer involves the use of the HSV thymidine kinase gene (HSV$t k)$ and the prodrug gancyclovir. Gancyclovir is used clinically as an antiviral agent against HSV, Epstein-Barr virus, and cytomegalovirus infection. ${ }^{121}$ Cells infected with these viruses produce a thymidine kinase that catalyses the conversion of gancyclovir to its active triphosphate form. The triphosphate form is incorporated into DNA and results in chain elongation termination, leading to the death of the cell. ${ }^{122}$ The concept of "suicide gene therapy" was initially described in the late 1980s, based on prodrug activation. ${ }^{123}{ }^{124}$ It was proposed that cancer cells be infected with a virus expressing HSV-tk, resulting in constituent expression of the drug activating enzyme in these cells. Subsequent exposure of these infected cancer cells to gancyclovir results in drug activation and death of malignant cells (fig 3). 


\section{HSV-tk}

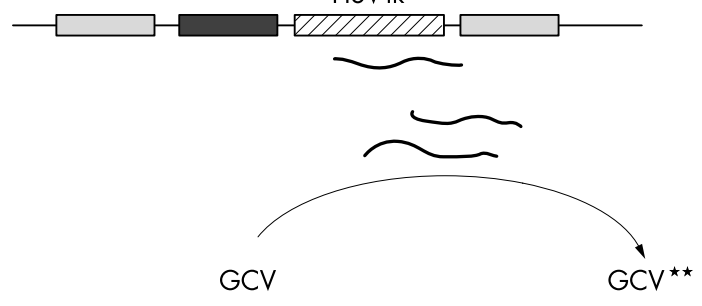

Inhibits DNA synthesis resulting in cell death

Figure 3 Suicide gene therapy. A virus expressing the drug activating enzyme, HSV-tk, is used to infect malignant cells. Malignant cells are then exposed to gancyclovir, which is activated to a cell lethal form by the HSV-tk enzyme. Cells not infected with the virus, and thus, not expressing HSV-tk, are not affected by the administration of gancyclovir. $\mathrm{GCV}$, gancyclovir; GCV**, activated gancyclovir.

Multiple clinical trials have been undertaken utilising the suicide gene therapy study. In 1998, a report of 21 patients with mesothelioma was published. Patients received intrapleural injection of adenovirus expressing HSV-tk followed by gancyclovir exposure. Multiple toxicity issues were reported with this study without clinical benefit being noted. ${ }^{125}$ In another trial, 18 patients with prostate adenocarcinoma were injected with adenovirus expressing HSV-tk followed by gancyclovir exposure. Multiple adverse effects were again noted, and only three patients experienced transient tumour regression. ${ }^{126}$

In 1997, Ram et al reported the treatment of refractory recurrent brain malignancy with suicide gene therapy. ${ }^{127}$ Survival benefit was not appreciated in the treated group. In a multinational study, 48 patients with recurrent gliablastoma multiforme received HSV-tk/adenovirus injections into the wall of the tumour cavity after resection, with subsequent gancyclovir exposure for 14 days. No clinical benefit was noted. ${ }^{128} \mathrm{~A}$ third trial, accessing the use of HSVtk/gancyclovir therapy for patients with recurrent primary or metastatic brain tumours, was undertaken and also failed to demonstrate significant clinical benefit. ${ }^{129}$

\section{Atherosclerosis}

Atherosclerosis remains one of the greatest health problems for developed countries. About 12 million Americans have coronary artery disease (CAD) and 1.1 million have a new myocardial infarction (MI) each year. ${ }^{130}{ }^{131}$ Advances have been made in the treatment of atherosclerosis, acute MI, and peripheral vascular disease (PVD); however, morbidity and mortality remain significant, as do treatment failures and rate of recurrence.

The value of collateral blood vessel supply to ischaemic tissue has been recognised for some time. Specifically, the extent of collateral blood vessel supply is inversely proportional to the extent of tissue damage incurred during an acute MI. Individuals lacking significant collaterals who suffer an acute event have more tissue damage and subsequent greater impairment of end organ function. Thus, collateral circulation is a natural "bypass" system, which is slow in developing, but effective at decreasing damage to tissue supplied by a diseased artery.

Consequently, it was proposed that the "bio-induction" of more effective collateral circulation could be used in patients who were not candidates for traditional surgical procedures and were failing medical management, or possibly to replace traditional forms of coronary artery bypass grafts (CABG) or stents.

Vascular endothelial growth factor (VEGF) became the leading candidate molecule for the induction of angiogenesis. ${ }^{132}$ However, the short half life of VEGF (about seven minutes) and the extended exposure time required to induce effective angiogenesis in animal models ${ }^{133}{ }^{134}$ was not compatible with protein infusion or injection techniques. Gene therapy was proposed as the appropriate form of delivery as it would allow for sustained, local protein delivery to ischaemic tissue over several weeks. The specific in vivo gene therapy strategy proposed was called "BioBypass". It consisted of an adenovirus modified to express the VEGF cDNA sequence, which was then injected into ischaemic tissue. Cells infected would express VEGF and induce angiogenesis into the region of ischaemia. The transient nature of adenovirus expression in cells allowed for continuous expression of VEGF for about four weeks. ${ }^{135}$ This time frame is long enough for angiogenesis, but short enough to limit potential side effects of persistent growth factor expression, including malignancy.

Toxicology studies in animals have demonstrated the safety and tolerability of BioBypass, ${ }^{136}{ }^{137}$ and therefore the concept has proceeded to clinical trials. Phase I clinical trials of 33 patients with limb ischaemia revealed improvement in exercise tolerability, increase ankle: brachial index, and quality of life after 20 injections of the adenovirus expressing VEGF into the affected ischaemic limb tissue. ${ }^{138}$ Unfortunately, more rigorous phase II trial results have recently been published and are disappointing. Results indicate that BioBypass did not effectively relieve ischaemia in patients with PVD after virus injection. ${ }^{139}$

Two related phase I trials have been conducted in patients with CAD. One study combined the intramyocardial injection of adenovirus expressing VEGF with concurrent CABG. The second study was conducted on non-surgical candidates failing maximum medical management, who received intramyocardial injection of virus though microscopic thoracotomy. Results indicated an increase in myocardial tissue perfusion and an increase in exercise tolerance after treatment. ${ }^{140}$ Further trials are pending.

\section{LIMITATIONS}

General limitations of current gene therapy technology include inefficient gene transfer. Viral vectors are extremely inefficient at transferring genetic material to human cells; even those with very high transduction efficiency in vitro fail to produce significant infection rates when applied to clinical trials. This factor played an important role in the escalation of dose in the ill fated University of Pennsylvania gene therapy clinical trial.

Another overarching issue is the lack of viral specificity. Current techniques do not allow for specific infection of cells; rather, cells in the vicinity of virus delivery are randomly infected. This issue has been partially addressed by the use of tissue specific promoters, which allow expression of the transgene only in tissue that can activate a specific promoter. However, this strategy is not amenable to all disease states and it continues to suffer from technical difficulties such as promoter "leakage" from endogenous viral sequences.

Another issue is the lack of long term transgene expression. Although not a concern in some clinical settings, as was demonstrated in PVD and CAD gene therapy, the need for long term expression of a therapeutic gene is essential in other strategies. For example, if the patients in the $\mathrm{AD}$ trial received fibroblasts that only expressed neurotrophic factor and salvaged neurones for one year, would the risk of the procedure outweigh the benefit considering that current 
medication also delays progression for approximately one year? The problem has been noted in multiple in vitro studies and animal studies where initial high levels of therapeutic protein have resulted in clinical responses, only to be lost several months later. ${ }^{141}$

A final issue, and perhaps most important, is that of controlled gene expression. The ability to turn "on" and "off" the expression of a therapeutic gene will be essential for those strategies requiring long term expression and those inducing inflammation or utilising growth factors. Induction of inflammation for treating such diseases as cancer may be useful, but once the cancer is cured the inflammation continues if bystander cells are expressing the inciting transgene. Chronic inflammation of a specific tissue is undesirable. Similarly, with the use of growth factors, uncontrolled growth factor expression and function is intimately involved in the malignant transformation processes. The continual expression of a growth factor predisposes to malignancy, as was noted by the researchers conducting the $\mathrm{AD}$ clinical trials. ${ }^{48}$ It is essential to be able to turn off growth factor expression if malignancy is detected, or if treatment is toxic or no longer deemed useful or necessary. To this end, progress has been made in the development of inducible promoter systems, for example, a tetracycline inducible promoter system has been defined in which the presence of tetracycline (which can be taken orally by patients) will allow the activation of a promoter sequence and result in subsequent therapeutic gene expression. In the absence of tetracycline, theoretically, the transgene is not expressed (fig 4). This "on/off" system allows for important dose delivery control. However, these systems are generally plagued by "leakage" of promoter activity and are currently imperfect. $^{142} 143$

\section{SAFETY ISSUES}

Since the approval of the first clinical gene therapy trial in 1988 and its commencement in 1989, over 3000 patients have been treated with gene therapy. Many of the initial safety considerations raised with early trials remain today. These can be broadly categorised as either pertaining to the delivery vector or the expression of the transferred gene.

The vast majority of clinical trials exploit viruses to transfer expression of genetic material to cells. Administration of a virus can result in inflammation or active infection. The risk
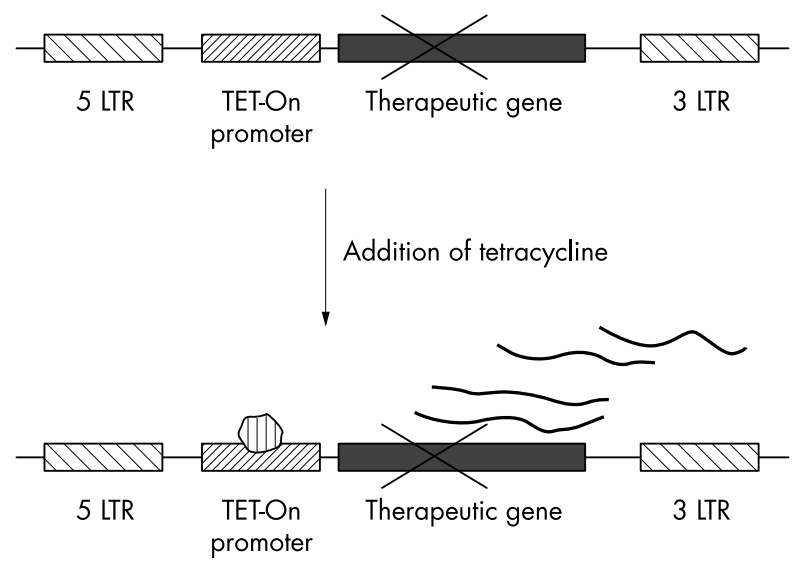

Figure 4 Controlled gene expression. The Tet-On system is an example of controlled gene expression. In the absence of tetracycline, the promoter is not activated and therefore therapeutic gene expression does not occur. However, when tetracycline is given to the patient the promoter sequence is activated and the therapeutic gene expressed; the wavy lines indicate gene transcription and translation into active protein. of overwhelming inflammation from virus administration was experienced firsthand during the University of Pennsylvania study, which resulted in the death of an 18 year old participant. $^{20}$ Secondly, active uncontrolled infection can occur either through multiple recombination events (unlikely given the current design) or through the contamination of replication incompetent viral stocks with a helper virus. There are no known cases of contaminated virus being delivered to patients, and clearly, the testing of material destined for clinical trials is essential and quite routine. Thirdly, the administration of retrovirus, which incorporates randomly into the genome, can result in insertional mutagenesis and malignant transformation. As mentioned previously, the treatment of severe combined immunodeficiency with autologous transplants of stem cells infected with a retrovirus expressing the deficient gene resulted in the alleviation of symptoms in patients. However, two of the 11 patients developed T cell leukaemia because the virus integrated downstream from an oncogene, resulting in its upregulation. ${ }^{21-24}$

The expression of various types of therapeutic genes predisposes patients to adverse effects. As mentioned earlier, the utilisation of growth factors for neurodegenerative disease or the use of proangiogenic molecules for CAD can promote tumour growth. Likewise, the expression of proinflammatory cytokines for the treatment of malignancy can result in aberrant inflammatory conditions. Although the administration of any therapeutic agent is associated with side effects, the complete inability to withdraw the agent delivered via gene therapy is particularly troublesome.

Finally, there is a theoretical risk of inadvertent alteration of germline cells. The event has been reported in animal models, but is yet to be accurately described after administration to humans.

\section{FUTURE DIRECTIONS}

New strategies for the application of gene transfer to the treatment of human disease are rapidly evolving. Two emerging techniques, RNA interference and exon skipping, hold particular promise.

RNA interference, or post-transcriptional gene silencing, was initially demonstrated in invertebrates and plants. ${ }^{144}$ The technique results in the selective and persistent suppression of gene expression and has been used extensively to study gene function. Briefly, double stranded RNA, homologous to the gene targeted for suppression, is introduced into cells where it is cleaved into small fragments of double stranded RNA named short interfering RNAs (siRNA). These siRNAs guide the enzymatic destruction of the homologous, endogenous RNA, preventing translation to active protein. ${ }^{145-148}$ They also prime RNA polymerase to synthesis more siRNA, perpetuating the process, and resulting in persistent gene suppression. ${ }^{149} 150$

To effectively silence specific genes in mammalian cells, Elbashu et al designed short hairpin RNA (shRNA). These sequences, which can be cloned into expression vectors and transferred to cells, result in the transcription of a double stranded RNA brought together by a hairpin loop structure (fig 5). These shRNAs effectively mimic siRNA and result in specific and persistent gene suppression in mammalian cells. ${ }^{151}$ Multiple groups have effectively incorporated shRNA coding sequences into AAV and lentiviral vectors and demonstrated specific gene suppression in mammalian cells. ${ }^{152-155}$

This technique has possible application to various disease states, including HIV infection. The suppression of specific viral protein expression could prevent viral replication and propagation. The technique could also suppress expression of 


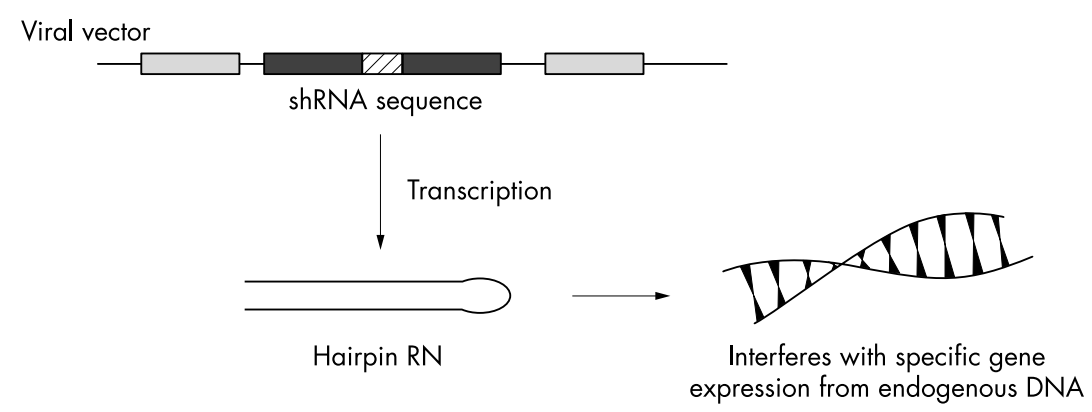

Figure 5 RNA interference and exon skipping. (A) RNA interference silences specific gene expression. The "turning off" of a gene is mediated by the expression of a short homologous RNA sequence from a viral vector that forms a hairpin. (B) Exon skipping is mediated by the expression of a short fragment of RNA that binds to a splice site (arrows). This prevents normal posttranscriptional modification and results in a protein with one fewer exon. In this example, the splice site before exon 2 is blocked $\left({ }^{*}\right)$ and exon 2 is spliced with the introns from the final transcript.

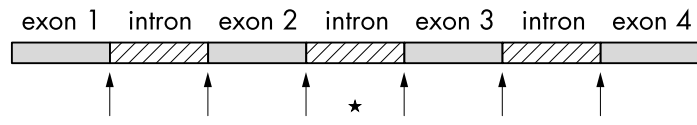

exon 1 exon 2 exon 3 exon 4

Normal post-transcriptional modification
Post-transcriptional modification after blocking the splice site with RNA exon skipping aberrant gene products or inflammatory proteins that may contribute to disease states.

A second emerging technique, exon skipping, may have important therapeutic implications for patients with DMD. The technique uses short sequences of RNA that are complementary to exon recognition sequences or exon splicing enhancer sequences. The expressed complementary RNA will bind to these regions of the gene and prevent the splicing of intron and exon at that site. ${ }^{156-158}$ The result of the altered post-transcriptional processing is the removal of a target exon from the final protein (fig 5).

This technique is particularly relevant to DMD. DMD results from frameshift mutations (reading frame is not preserved) that produce a completely aberrant protein. However, the less severe phenotype, Becker's muscular dystrophy (BMD), results from an in frame mutation (reading frame is preserved) in the same gene. Thus, an exon with an insertion or deletion that disrupts the reading frame of the dystrophin gene (producing DMD) could be spliced out using the exon skipping technique. The reading frame would be maintained and the dystrophin gene would be converted from a frame shift mutation to an in frame mutation. More importantly, a patient with DMD could be converted to a BMD phenotype, resulting in decreased morbidity and prolonged life expectancy. ${ }^{159} 160$

\section{CONCLUSION}

In conclusion, gene therapy continues to offer great promise in treating disease for which ineffective modalities exist or no options are available. The basic paradigm for gene delivery has been constant for some time, in vivo and ex vivo. However, the strategies to deliver genetic material within these paradigms are highly variable and new, insightful techniques emerge continuously. Currently gene therapy based clinic trials are being conducted in many of the major disease processes and in rare, usually well defined, genetic disorders. As basic science continues to progress within the field, more effective clinical trials will be launched and eventually will successfully treat or even cure patients. As this occurs, it will be essential for all physicians to understand the basic concepts encompassing a complex field.

\section{APPENDIX 1: GLOSSARY OF TERMS}

Autologous: Donor cells and recipient organism are the same; in contrast to heterologous in which cells and recipient are genetically different.

Antigenicity: The potential to act as an antigen and induce an inflammatory immune response.

Cell culture: Refers to growing cells in an artificial environment, using a flask, synthesised medium, and an incubator.

Copy number: The number of individual genes that were transferred to a cell. Generally, this level correlates with level of gene product.

Exon skipping: A technique that allows selected exons to be deleted from the final protein. The process is mediated by transcription of sequences homologous to exon splice sites.

Expression: Refers to the transcription and translation of a bioactive protein in a cell.

Ex vivo gene therapy: A two step strategy to transfer genetic material to an organ system. The first step involves the transfer of the gene to a surrogate cell. The second step involves the transfer of the surrogate cell, expressing a therapeutic protein, to an organ system.

Frame shift mutation: A mutation that disrupts the RNA reading frame, resulting in a completely abnormal amino acid protein sequence after the mutation. In contrast, "in frame" mutations preserve the original reading frame, and therefore, after the mutation the amino acid sequence of the protein is unchanged from the wild type protein.

Helper virus: A virus (usually contaminant) that aids in the replication of a virus that by itself cannot replicate.

Integrate: The permanent incorporation of a DNA sequence into the genome of a cell, resulting in its persistence after cell division. 
In vitro: Refers to the artificial environment of culture flasks and supplemented medium.

In vivo: Refers to the natural environment.

In vivo gene therapy: A strategy to deliver genetic material by directly administering the transfer vector to target cells.

Monoclonal: A population of cells derived from one cell; these cells should be genetically identical.

Packaging cell line: A cell line that is engineered to produce virus particles.

Polyclonal: A population of cells derived from multiple cells. These cells are genetically and phenotypically heterogenic.

Post-transcriptional gene silencing (RNA interference): A technique used to suppress the expression of an endogenous gene. The process is mediated by the expression of short pieces of RNA that are homologous to the gene targeted for suppression.

Replication incompetent virus: A virus that is limited to one round of infection.

Self replicating virus (replication competent): A virus that can infect cells and subsequently produce infectious progeny to infect further cells.

shRNA (short hairpin RNA): Short RNA sequences that form a hairpin structure after transcription. The shRNA will interfere with endogenous gene expression in mammalian cells and is homologous in function to siRNA.

siRNA (short interfering RNA): Short pieces of RNA that bind to endogenous RNA sequences and mediate their degradation, preventing translation to a protein.

Subclone: A monoclonal population isolated from a polyclonal population.

Surrogate cell: A cell type used to transfer expression of a therapeutic protein to an organ system.

Therapeutic gene: A gene transferred to a cell, which when expressed will hypothetically alter disease course favourably.

Transgene: Synomonous with "gene of interest" and "therapeutic gene".

Viral vector: Altered virus that has been engineered to contain one or several genes of interest in addition to viral sequences that code for transcriptional and packaging signals and viral structural proteins. This structure "carries" the therapeutic gene to cells so that it can be expressed.

\section{REFERENCES}

1 Friedman T, Roblin R. Gene therapy for human genetic disease? Science 1972; 175:949-55

2 Anderson WF. Prospects for human gene therapy. Science

1984:226:401-9.

3 Miller AD. Human gene therapy comes of age. Nature 1992;357:45560.

4 Anderson WF. Human gene therapy. Science 1992;256:808-13.

5 Rogers S, Pfuderer P. Use of viruses as carriers of added genetic information. Nature 1968;219:749-51.

6 Graham FL, Van der Eb AJ. A new technique for the assay of infectivity of human adenovirus DNA. Virology 1973;52:456-67.

7 Wigler M, Pellicer A, Silverstein S, et al. Transfer of single-copy eukaryotic genes using total cellular DNA as donor. Cell 1978;14:725-31.

8 Mulligan RC, Berg P. Factors governing the expression of a bacterial gene in mammalian cells. Mol Cell Biol 1981a; 1:449-59.

9 Mulligan RC, Berg P. Selection for animal cells that express the Escherichia coli gene for xanthine-guanine phosphoribosyltransferase gene. Proc Natl Acad Sci USA 1981b;78:2072-6.

10 Mercola KE, Stang HD, Browne J, et al. Insertion of a new gene of viral origin into bone marrow cells of mice. Science 1980;208:1033-5.

11 Wade N. UCLA gene therapy racked by friendly fire. Science 1980;210:509-11.

12 Anderson WF, Fletcher JC. Gene therapy in human beings: when is it ethical to begin? N Engl J Med 1980;303:1293-7.

13 Temin HM. Malignant transformation of cells by viruses. Perspect Biol Med 1970;14:11-26.

14 Temin HM. Mechanism of cell transformation by RNA tumor viruses. Annu Rev Microbiol 1971;25:609-48.

15 Temin HM. The DNA provirus hypothesis. Science 1976;192:1075-80.

16 Shimotohno K, Temin HM. Formation of infectious progeny virus after insertion of herpes simplex thymidine kinase gene into DNA of an avian retrovirus. Cell 1981;26:67-77.

17 Wei CM, Gibson M, Spear PG, et al. Construction and isolation of a transmissible retrovirus containing the src gene of Harvey murine sarcoma virus and the thymidine kinase gene of herpes simplex virus type 1. J Virol 1981;39:935-44

18 Tabin CJ, Hoffmann JW, Goff SP, et al. Adaptation of a retrovirus as a eucaryotic vector transmitting the herpes simplex virus thymidine kinase gene. Mol Cell Biol 1982;2:426-36.

19 Eliot M. Gene therapy death prompts review of adenovirus vector. Science 1999;286:2244-5

20 Vogel G. Gene therapy. FDA moves against PENN scientist. Science 2000;290:2049-51.

21 Cavazzana-Calvo M, Hacein-Bey S, de Saint Basile G, et al. Gene therapy of human severe combined immunodeficiency (SCID)-X1 disease. Science 2000;288:627-9.

22 Hacein-Bey-Abina S, Fischer A, Cavazzana-Calvo M. Gene therapy of Xlinked severe combined immunodeficiency. Int J Hematol 2002;76:295-8.

23 Hacein-Bey-Abina S, von Kalle C, Schmidt M, et al. A serious adverse event after successful gene therapy for $X$-linked severe combined immunodeficiency. N Engl J Med 2003;348:255-6.

24 Hacein-Bey-Abina S, Von Kalle C, Schmidt M, et al. LMO2-associated clonal $T$ cell proliferation in two patients after gene therapy for SCID-X1. Science 2003;302:415-19.

25 Miller DG, Adam MA, Miller AD. Gene transfer by retrovirus vectors occurs only in cells that are actively replicating at the time of infection. Mol Cell Biol 1990; 10:4239-42.

26 Johnson P, Miyanohura A, Levind F, et al. Cytotoxicity of a replication defective mutant of herpes simplex virus type 1. J Virol 1992;66:2952-65.

27 Chiocca EA, Choi BB, Cai WZ, et al. Transfer and expression of the lacZ gene in rat brain neurons mediated by herpes simplex virus mutants. New Biology 1990;2:739-46

28 Burton EA, Wechuck JB, Wendell SK, et al. Multiple applications for replication-defective herpes simplex virus vectors. Stem Cells 2001;19:358-77.

29 Goss JR, Goins WF, Lacomis D, et al. Herpes simplex-mediated gene transfer of nerve growth factor protects against peripheral neuropathy in streptozotocin-induced diabetes in the mouse. Diabetes 2002;51:2227-32.

30 Chattopadhyay M, Wolfe D, Huary S, et al. In vivo gene therapy for pyridoxine-induced neuropathy by herpes simplex virus-mediated gene transfer of neurotrophin-3. Ann Neurol 2002;51:19-27.

31 Pulkkauen KJ, Parkkinen JJ, Laukkanes JM, et al. HSV-tk gene therapy for human renal cell carcinoma in nude mice. Cancer Gene Ther $2001 ; 8: 529-36$

32 Solly SK, Trajcerski S, Frisen C, et al. Replicative retroviral vectors for cancer gene therapy. Cancer Gene Ther 2003;10:30-9.

33 Uchida E, Mizugrechi H, Ishii-Watabe A, et al. Comparison of the efficiency and safety of nonviral vector-mediated gene transfer into a wide range of human cells. Biol Pharm Bull 2002;25:891-7.

34 Byrnes AP, Rusby JE, Wood MJA, et al. Adenovirus gene transfer causes inflammation in the brain. Neuroscience 1995;66:1015-24.

35 Mitani K, Kubo S. Adenovirus as an integrating vector. Curr Gene Ther 2002;2:135-44

36 Kaplitt MG, Leone P, Samulski RJ, et al. Long-term gene expression and phenotypic correction using adeno-associated virus vectors in the mammalian brain. Nat Genet 1994;8:148-54

37 Monahan PE, Jooss K, Sands MS. Safety of adeno-associated virus gene therapy vectors: a current evaluation. Expert Opinion Drug Safety 2002;1:79-91.

38 Owens RA. Second generation adeno-associated virus type 2 based gene therapy systems with the potential for preferred integration into AAVS. Cur Gene Ther 2002;2:145-59.

39 Kochanek S, Schieelner G, Volpers G. High capacity "gutless" adenoviral vectors. Curr Opin Mol Ther 2001;3:454-63.

40 Bukrinsky MI, Haggerty S, Dempsey MP, et al. A nuclear localization signal within HIV-1 matrix protein that governs infection of non-dividing cells. Nature 1993;365:666-9

41 Amado RG, Chen ISY. Lentiviral vectors - the promise of gene therapy within reach. Science 1999;285:674-6.

42 Yee JK, Zaia JA. Prospects for gene therapy using HIV-based vectors. Somatic Cell Mol Genet $2001 ; 26: 159-74$.

43 Ikeda Y, Goto Y, Yonemitsu Y, et al. Simian immunodeficiency virus-based lentivirus vector for retinal gene transfer: a preclinical safety study in adult rats. Gene Ther 2003;10:1161-9.

44 Thomas CE, Ehrhardt A, Kay MA. Progress and problems with the use of viral vectors for gene therapy. Nat Rev Genet 2003;4:346-58.

45 Selkirk SM, Greenberg SJ, Plunkett RJ, et al. Syngeneic central nervous system transplantation of genetically transduced mature, adult astrocytes. Gene Ther 2002;9:432-43.

46 Horellou $\mathrm{P}$, Brundin $\mathrm{P}$, Kalen $\mathrm{P}$, et al. In vivo release of dopa and dopamine from genetically engineered cells grafted to the denervated rat striatum. Neuron 1990;5:393-402.

47 Tuszynsiki MH, Roberts J, Senut MC, et al. Gene therapy in the adult primate brain: intraparenchymal grafts of cells genetically modified to produce nerve growth factor prevent cholinergic neuronal degeneration. Gene Ther 1996;3:305-14.

48 Tuszynsiki MH. Growth-factor gene therapy for neurodegenerative disorders. Lancet Neurol 2002;1:51-7.

49 Kawaja MD, Gage FH. Morphological and neurochemical features of cultured primary skin fibroblasts of Fischer 344 rats following striatal implantation. J Comp Neurol 1992;317:102-16.

50 Eglitis MA, Dawson D, Park K-W, et al. Targeting of marrow-dervied astrocytes to the ischemic brain. Neuroreport 1999;10:1289-92.

51 Yang R, Liu YH, Yang XP, et al. Myocardial infarction and cardiac remodeling in mice. Exp Physiol 2002;87:547-55. 
52 Orlic D, Kagstura J, Chimenti $S$, et al. Bone marrow stem cells regenerate infarcted myocardium. Pediatr Transplant 2003;7(suppl 3):86-8.

53 Case SS, Price MA, Jordan CT, et al. Stable transduction of quiescent CD34+ CD38- human, hematopoitic cells by HIV-1 based lentiviral vectors. Proc Natl Acad Sci USA 1999:96:2988-93.

54 Douglas J, Kelly P, Evans JT, et al. Efficient transduction of human lymphocytes and CD34+ cells via human immunodeficiency virus-based gene transfer vectors. Hum Gene Ther 1999;10:935-45.

55 Andreoletti M, Loux N, Vons C, et al. Engraftment of autologous retroviral transduced hepatocytes after intraportal transplantation into nonhuman primates: implications for ex vivo gene therapy. Hum Gene Ther 2001;12:169-79.

56 Lois C, Alvarez-Buylla D. Proliferating subventricular zone cells in the adult mammalian forebrain can differentiate into neurons and glia. Proc Natl Acad Sci USA 1993;90:2074-7.

57 Johansson CB, Momma S, Clarla DL, et al. Identification of a neural stem cell in the adult mammalian central nervous system. Cell 1999;96:25-34.

58 Lin Q, Cunninghan LA, Epstein LG, et al. Human fetal astrocytes as an ex vivo gene therapy vehicle for delivering biologically active nerve growth factor. Hum Gene Ther 1997;8:331-9.

59 Pesce $M$, Orlandi $A$, lachininoto $M G$, et al. Myoendothelial differentiation of human umbilical cord blood-derived stem cells in ischemic limb tissues. Circ Res 2003;93:e51-62.

60 Ishikawa F, Drake CJ, Yang S, et al. Transplanted human cord blood cells give rise to hepatocytes in engrafted mice. Ann N Y Acad Sci 2003;996:174-85

61 Dowell JD, Rubart $M$, Pasumarthi KB, et al. Myocyte and myogenic stem cell transplantation in the heart. Cardiovasc Res 2003;58:336-50.

62 Zalzman M, Gupta S, Giri RK, et al. Reversal of hyperglycemia in mice by using human expandable insulin-producing cells differentiated from fetal liver progenitor. Proc Natl Acad Sci USA 2003;10:7253-8.

63 Biorklund A, Steneri U. Reconstruction of the nigral striatal dopamine pathway by intracerebral nigral transplant. Brain Res 1979;117:555-60.

64 Lindvall $\mathrm{O}$, Brundin $\mathrm{P}$, Widner $\mathrm{H}$, et al. Grafts of fetal dopamine neurons survive and improve motor function in Parkinson's disease. Science 1990;247:574-7.

65 Widner $\mathrm{H}$, Tetrud J, Rehncrona S, et al. Bilateral fetal mesecephalic grafting in two patients with parkinsonism induced by 1-methyl-4-phenly-1,2,3,6tetrahydropyridine. N Engl I Med 1992;327:1556-63.

66 Piccini P, Brooks DJ, Bjorklund A, et al. Dopamine release from nigral transplants visualized in vivo in a Parkinson's patient. Nat Neurosci 1999;2:1137-40.

67 Piccini P, Lindvall O, Bjorklund A, et al. Delayed recovery of movementrelated cortical function in Parkinson's disease after striatal dopaminergic grafts. Ann Neurol 2000;48:689-95.

68 Mendez I, Dagher A, Hong M, et al. Simultaneous intrastriatal and intranigral fetal dopaminergic grafts in patients with Parkinson disease, a pilot study: report of three cases. J Neurosurg 2002;96:589-96.

69 Pakzaban P, Deacon T, Burns L, et al. Increased proportion of AchE-rich zones and improved morphologic integration in host striatum of fetal grafts derived from the lateral but not medial ganglionic eminence. Exp Brain Res 1993;97:13-22.

70 Isaacson O, Deacon T, Pakzaban P, et al. Transplanted xenogenic neural cells in neurodegenerative disease models exhibit remarkable axonal targe specificity and distinct growth patterns of glial and axonal fibers. Nat Med 1995;1:1 189-94.

71 Freeman TB, Sanberg PR, Isacson O. Development of the human striatum: Implications for fetal striatal transplantation. Cell Transplant 1995;4:539-45.

72 Weir GC, Bonner-Weir S, Leahy JL. Islet mass and function in diabetes and transplantation. Diabetes 1990;39:401-5.

73 Ryan EA, Lakey JR, Paty BW, et al. Successful islet transplantation: continued insulin reserve provides long-term glycemic control. Diabetes 2002;51:21 48-57.

74 Riordan JR, Rommens JM, Kerem BS, et al. Identification of the cystic fibrosis gene: cloning and characterization of complementary DNA. Science 1989;245:1066-73.

75 Collins FS. Cystic fibrosis: molecular biology and therapeutic implications. Science 1992;256:774-9.

76 Cystic Fibrosis Genetic Analysis Consortium. Cystic fibrosis mutation database. Available at: http://www.genet.sickkids.on.ca/cttr (accessed 1 February 2004).

77 Cystic Fibrosis Foundation. Cystic Fibrosis Foundation Patient Registry annual report 2000. Bethesda: Cystic Fibrosis Foundation, 2001.

78 Crystal RG, McElvaney NG, Rosenfeld MA, et al. Administration of an adenovirus containing the human CFTR CDNA to the respiratory tract of individuals with cystic fibrosis. Nat Genet 1994;8:42-51.

79 Flotte T, Carter B, Conrad C, et al. A phase I study of an adeno-associated virus-CFTR gene vector in adult CF patients with mild lung disease. Hum Gene Ther 1996;7:1145-59.

80 Wagner JA, Reynolds T, Moran ML, et al. Efficient and persistent gene transfer of AAV-CFTR in maxillary sinus. Lancet 1998;351:1702-3.

81 Aitken ML, Moss RB, Waltz DA, et al. A phase I study of aerosolized administration of tgAAVCF to cystic fibrosis subjects with mild lung disease. Hum Gene Ther 2001;12:1907-16.

82 Wagner JA, Nepomuceno IB, Messner AH, et al. A phase II, double-blind randomized, placebo-controlled clinical trial of tgAAVCF using maxillary sinus delivery in patients with cystic fibrosis with antrostomies. Hum Gene Ther 2002;13:1349-59.

83 Flotte TR, Zeitlin PA, Reynolds TC, et al. Phase I trial of Intranasal and Endobronchial administration of a recombinant adeno-associated virus serotype 2 (rAAV2)-CFTR vector in adult cystic fibrosis patients: a two-part clinical study. Hum Gene Ther 2003;14:1079-88.

84 Cystic Fibrosis Foundation. Available at: http:// www.cff.org/research/ genetic_studies_aavcftr_gene_transfer_agent.cfm (accessed 20 January 2004).

85 Zabner J, Cheng SH, Meeker D, et al. Comparison of DNA-lipid complexes and DNA alone for gene transfer to cystic fibrosis airway epithelia in vivo. $J$ Clin Invest 1997;100:1529-37.

86 Porteous DJ, Dorin JR, McLachlan G, et al. Evidence for safety and efficacy of DOTAP cationic liposome mediated CFTR gene transfer to the nasal epithelium of patients with cystic fibrosis. Gene Ther 1997:4:210-18.

87 Chadwick SL, Kingston HD, Stern M, et al. Safesty of a single aerosol administration of escalating doses of the cationic lipid GL-67/DOPA/DMPEPEG5000 formulation to the lungs of normal volunteers. Gene Ther 1997;4:937-42.

88 Knowles MR, Noone PG, Hohneker K, et al. A double-blind, placebo controlled, dose ranging study to evaluate the safety and biological efficacy of the lipid-DNA complex GR213487B in the nasal epithelium of adult patients with cystic fibrosis. Hum Gene Ther 1998:9:249-69.

89 Lin G, Li D, Pasumarthy MK, et al. Nanoparticals of compacted DNA transfect post mitotic cells. J Biol Chem 2003;278:32578-86.

90 Ziady AG, Gedeon GR, Muhammad O, et al. Minimal toxicity of stabilized compacted DNA nanoparticles in murine lung. Mol Ther 2003;8:948-56.

91 Copernicus Therapeutics. Press release. Available at: copernicustherapeutics.com/pdf/Cystic_Fibrosis_Clinical_Trial_Results 042903.pdf

92 Nobile C, Marchi J, Nigro V, et al. Exon-intron organization of the human dystrophin gene. Genomics 1997:45:421-24.

93 Ohlendieck K, Matsumura K, lonasescu N, et al. Duchenne muscular dystrophy deficiency of dystrophin-associated protein in the sarcolemma Neurology 1993;43:795-800

94 Thiodellet C, Blot S, Squiban P, et al. Current protocol of a research phase I clinical trial of full-length dystrophin plasmid DNA in Duchenne/Becker muscular dystrophies. Part I: rationale. Neuromusc Disord 2002;12:S49-51

95 Romero NB, Benveniste O, Payan C, et al. Current protocol of a research phase I clinical trial of full-length dystrophin plasmid DNA in Duchenne/ Becker muscular dystrophies. Part II: clinical protocol. Neuromusc Disord 2002; 12:S45-8.

96 Leifer E. Early diagnosis of Alzheimer's disease: clinical and economic benefits. J Am Ger Soc 2003;51:S281-8.

97 Tariot PN. Maintaining cognitive function in Alzheimer disease: how effective are current treatments? Alzheimer Dis Assoc Disord 2001;15(suppl 1):S26-33.

98 Farlow M. A clinical overview of cholinesterase inhibitors in Alzheimer's dementia. Int Psychoger 2002;4(suppl 1):93-126.

99 Locca P, Cocuzza E, Marchiaro L, et al. Donepexil I n the treatment of Alzheimer's disease: long term efficacy and safety. Prog Neuropsychopharmocol Biol Psychiatry 2002;26:369-73.

100 Levi-Montalcini R, Hamburger V. Selective growth stimulating effects of mouse sarcoma on the sensory and sympathetic nervous system of the chick embryo. J Exp Zool 1951;116:321-62.

101 Hefti F. Nerve growth factor (NGF) promotes survival of septal cholinergic neurons after fimbrial transection. I Neurosci 1986;6:2155-62.

102 Williams LR, Varon S, Peterson GM, et al. Continuous infusion of nerve growth factor porevents basal forebrain neuronal death after fimbria-fornix transection. Proc Natl Acad Sci USA 1986:83:9231-5.

103 Kromer LF. Nerve growth factor treatment after brain injury prevents neuronal death. Science 1987;235:214-16.

104 Winkler J, Ramirez GA, Kuhn HG, et al. Reversible induction of Schwann cell hyperplasia and sprouting of sensory and sympathetic neuritis in vivo after continuous intracerebroventricular administration of nerve growth factor. Ann Neurol 1996;40J:128-39.

105 Williams LR. Hypophagia is induced by intracerebroventricular administration of nerve growth factor. Exp Neurol 1991:113:31-7.

106 Isaacson LG, Saffran BN, Crutcher KA. Intracerebral NGF infusion induces hyperinnervation of cerebra blood vessels. Neurobiol Aging 1990;1 1:51-5.

107 Eriksdotter JM, Nordberg A, Amberla K, et al. Intracerebrobentricular infusion of nerve growth factor in three patients with Alzheimer's disease. Dement Geriatr Cogn Disord 1998:9:246-57.

108 Chen KS, Gage FH. Somatic gene transfer of NGF to the aged brain: behavioral and morphological amelioration. J Neurosci 1995; 15:2819-25.

109 Smith DE, Roberts J, Gage FH, et al. Age-associated neuronal atrophy occurs in the primate brain and is reversible by growth factor gene therapy. Proc Natl Acad Sci USA 1999:96:10893-8.

110 Silverberg E, Boring CC, Squires TS. Cancer statistics. CA: American Cancer Society Inc, 1990;40:9-26.

111 Sagar R. Tumor suppressor genes; the puzzle and the promise. Science 1989:246:1406-12.

112 Klein G. The approaching era of the tumor suppressor gene. Science 1987;238:1539-45.

113 Weinberg RA. Oncogenes and tumor suppressor genes. Cancer J Clin 1994;44:160-70.

114 Nigro JM, Baker SJ, Preisiyer AC, et al. Mutations in the p53 gene occur in diverse human tumor types. Nature 1989;342:705-8.

115 Lang FF, Brunew JM, Fuller GN, et al. Phase I trial of adenovirus-mediated P53 gene transfer for recurrent glioma: biological and clinical results. J Clin Oncol 2003;21:2508-18.

116 Swisher SG, Roth JA, Komaki R, et al. Induction of P53-regulated genes and tumor regression in lung cancer patients after intratumoral delivery of adenoviral P53 (INGN 201) and radiation therapy. Clin Cancer Res 2003;9:93-101. 
117 Buller RE, Runnebaum IB, Karlan BY, et al. A phase I/II trial of rAD/P53 (SCA 585000) gene replacement in recurrent ovarian cancer. Cancer Gene Ther 2002;9:553-66.

118 National Institutes of Health. Chemotherapy combined with gene therapy in treating patients who have stage III or stage IV breast cancer. Available at: http://clinicaltrials.gov/ct/show/nct00044993?order $=1$.

119 National Institutes of Health. Chemotherapy with or without gene therapy in treating patients with recurrent head and neck cancer. Available at: http:// clinicaltrials.gov/ct/show/NCT00040716? order $=2$.

120 Zeimet AG, Martha C. Why did P53 gene therapy fail in ovarian cancer? Lancet Oncol 2003;4:415-22.

121 Faulds D, Heel RC. Ganciclovir. A review of its antiviral activity, pharmacokinetic properties and therapeutic efficacy in cytomegalovirus infections. Drug 1990:39:597-638.

122 lisley DD, Lee SH, Miller WH, et al. Acyclic guanosine analogs inhibit DNA polymerases alpha, delta, and epsilon with very different potencies and have unique mechanisms of action. Biochemistry 1995;34:2504-10.

123 Moolten FL. Tumor chemosensitivity conferred by inserted herpes thymidine kinase genes: paradigm for a prospective cancer control strategy. Cancer Res 1986;46:5276-81.

124 Moolten FL. An alternative to the magic bullet paradigm for specific cancer therapy. Med Hypotheses 1987;24:43-51.

125 Molnar-Kimber KL, Sterman DH, Chang M, et al. Impact of preexisting and induced humoral and cellular immune responses in an adenovirus-based gene therapy phase I clinical trial for localized mesothelioma. Hum Gene Ther 1998;9:2121-33

126 Herman JR, Adler HI, Aguilar-Cordova F, et al. In situ gene therapy for adenocarcinoma of the prostate: a phase I clinical trial. Hum Gene Ther 1999; 10:1239-49

127 Ram Z, Culver KW, Oshiro EM, et al. Therapy of malignant brain tumors by intratumoral implantation of retroviral vector-producing cells. Nat Med 1997;3:1354-61.

128 Shand N, Weber F, Mariani L, et al. A phase 1-2 clinical trial of gene therapy for recurrent glioblastoma multiforme by fumor transduction with the herpes simplex thymidine kinase gene followed by ganciclovir. GLI328 European-Canadian Study Group. Hum Gene Ther 1999;10:2325-35.

129 Trask TW, Trask RP, Aguilar-Cordova E, et al. Phase I study of adenoviral delivery of the HSV-tk gene and ganciclovir administration in patients with current malignant brain tumors. Mol Ther 2000;1:195-203.

130 Kilaru PK, Kelly RF, Calvin JE, et al. Utilization of coronary angiography and revascularization after acute myocardial infarction in men and women risk stratified by the American College of Cardiology/American Heart Association guidelines. J Am Coll Cardiol 2000;35:9784-90.

131 Eagle KA, Guyton RA, Daviddoff R, et al. ACC/AHA guidelines for coronary artery bypass graft surgery: a report of the American College of Cardiology/ American Heart Association Task Force on Practice Guidelines. J Am Coll Cardiol 1999:34:1262-347.

132 Ferrara N, Houck K, Jakeman L, et al. Molecular and biological properties of the vascular endothelial growth factor family of proteins. Endocr Rev 1992;13:18-32.

133 Banai S, Jaklitsch MT, Shou M, et al. Angiogenic-induced enhancement of collateral blood flow to ischemic myocardium by vascular endothelial growth factor in dogs. Circulation 1994;89:2183-9.

134 Takeshita S, Yuko T, Thierry C, et al. Therapeutic angiogenesis. A single intraarterial bolus of vascular endothelial growth factor augments revascularization in a rabbit ischemic hind limb model. J Clin Invest 1994;93:662-70.

135 Brody SL, Crystal RG. Adenovirus-mediated in vivo gene transfer. Ann N Y Acad Sci 1994;16:90-103.

136 Safi J, DiPaula AF, Riccioni T, et al. Adenovirus-mediated acidic fibroblast growth factor gene transfer induces angiogenesis in the non-ischemic rabbit heart. Microvasc Res 1999;58:238-49.

137 Mack CA, Patel SR, Schwartz EA, et al. Biologic bypass with the use of adenovirus-mediated gene transfer of the complementary deoxyribonucleic acid for vascular endothelial growth factor 121 improves myocardial perfusion and function in the ischemic porcine heart. J Thorac Cardiovasc Surg 1998;115:168-77.
138 Rajagopalan S, Trachtenberg J, Mohler E, et al. Phase I study of direct administration of a replication deficient adenovirus vector containing the vascular endothelial growth factor cDNA (C1-1023) to patients with claudication. Am J Cardiol 2002;90:512-16.

139 Rosenjart TK, Lee LY, Patel SR, et al. Angiogenesis gene therapy: phase I assessment of direct intramyocardial administration of an adenovirus vector expressing VEGF121 cDNA to individuals with significant severe coronary artery disease. Circulation 1999;100:468-74.

140 Rajagopalan S, Mohler E, Lederman RJ, et al. Regional angiogenesis with vascular endothelial growth factor in peripheral arterial disease: a phase II randomized, double-blind, controlled study of adenoviral delivery of vascular endothelial growth factor 121 in patients with disabling intermittent claudication. Am Heart J 2003;145:1114-18.

141 Palmer TD, Rosman GJ, Osborne WR, et al. Genetically modified skin fibroblasts persist long after transplantation but gradually inactivate introduced genes. Proc Natl Acad Sci USA 1991;88:1330-4.

142 Gossen M, Bonin AL, Freundlieb S, et al. Inducible gene expression systems for higher eukaryotic cells. Current Opinion of Biotechnology 1994:5:516-20.

143 Blesch A, Conner JM, Tuszynski MH. Modulation of neuronal survival and axonal growth in vivo by tetracycline-regulated neurotrophin expression. Gene Ther 2001;8:954-60.

144 Hannon GJ. RNA interference. Nature 2002;418:244-51.

145 Nykanen A, Haley B, Zamore PD. ATP requirements and small interfering RNA structure in the RNA interference pathway. Cell 2001;107:309-21.

146 Hammond SM, Bernstein E, Beach D, et al. An RNA-directed nuclease mediates post-transcriptional gene silencing in drosophila cells. Nature 2000:404:293-6.

147 Zamore PD, Tuschl T, Sharp PA, et al. RNAi: double-stranded RNA directs the ATP-dependent cleavage of mRNA at 21 to 23 nucleotide intervals. Cell 2000;101:25-33.

148 Bass BL. RNA interference. The short answer. Nature 2001;41 1:428-429

149 Sijen T, Fleenor J, Slimmer $F$, et al. On the role of RNA amplification in dsRNA-triggered gene silencing. Cell 2001;107:465-76.

150 Lipardi C, Wei Q, Paterson BM. RNAi as random degradative PCR: siRNA primers convert mRNA into dsRNAs that are degraded to generate new siRNAs. Cell 2001;107:297-307.

151 Elbashir SM, Harborth J, Lendeckel W, et al. Duplexes of 21-nucleotide RNAs mediate RNA interference in cultured mammalian cells. Nature 2001;411:494-8.

152 Van Den Haute C, Effermont K, Nuttin B, et al. Lentiviral vector-mediated delivery of short hairpin RNA results in persistent knockdown of gene expression in mouse brain. Hum Gene Ther 2003:14:1799-807.

153 Rubinson DA, Dillion CP, Kwiatkowski AV, et al. A lentivirus-based system to functionally silence genes in primary mammalian cells, stem cells and transgenic mice by RNA interference. Nat Genet 2003;33:401-6.

154 Abbas-Tefki T, Blanco-Bose W, Deglon N, et al. Lentiviral-mediated RNA interference. Hum Gene Ther 2002;13:2197-201.

155 Hommel JD, Sears RM, Georgescu D, et al. Local gene knockdown in the brain using viral-mediated RNA interference. Nat Med 2003;9:1539-44.

156 Van Deutekom JC, Bremmer-Bout M, Janson AS, et al. Antisense-induced exon skipping restores dystrophin expression in DMD patient derived muscle cells. Hum Mol Genet 2001;10:1547-54.

157 Mann CJ, Honeyman K, Cheng AJ, et al. Antisense-induced exon skipping and synthesis of dystrophin in the mdx mouse. Proc Natl Acad Sci USA 2001:98:42-7.

158 Dunckley MG, Manoharan M, Villiet $P$, et al. Modification of splicing in the dystrophin gene in cultured Mdx muscle cells by antisense oligoribonucleotides. Hum Mol Genet 1998;7:1083-90.

159 Aartsma-Rus A, Janson AAM, Kaman WE, et al. Therapeutic antisenseinduced exon skipping in cultured muscle cells from six different DMD patients. Hum Mol Genet 2003;12:907-14.

160 De Angelis FG, Sthandier O, Berarducci B, et al. Chimeric snRNA molecules carrying antisense sequences against the splice junctions of exon 51 of the dystrophin pre-mRNA induce exon skipping and restoration of a dystrophin synthesis in delta 48-50 DMD cells. Proc Natl Acad Sci USA 2001;98:9456-61. 